\title{
Academic Feminisms: Between Disidentification, Messy Everyday Utopianism, and Cruel Optimism
}

\author{
Nina Lykke ${ }^{1 *}$
}

Published: October 30, 2017

\begin{abstract}
This article reviews current debates on epistemic habits of critique and affirmation, specifically focusing on approaches which combine criticality with ways to encourage unfoldings of alternative futurities, figurations and worlding practices. Embedded in a process of critical self-reflection regarding epistemic habits, the article discusses disidentification (Butler 1993, Muñoz 1999), cruel optimism (Berlant 2011), and everyday utopianism (Cooper 2014) understood as examples of such habits. The article explores how feminisms, unfolding within academia, and thus institutionally embedded in the logics of global capitalism, neoliberalism and particular nation-state politics, on the one the hand, are bound to a performance of cruel optimism, glossing over dilemmas and contradictions, and, on the other hand, perhaps enabled to enact messy kinds of everyday utopianism. Finally, the article reflects upon possibilities for changing one's epistemic habits, suggesting a couple of changes: to systematically integrate reflections on changing conditions of academic knowledge production, as well as on geopolitical grammars. These issues are addressed as being interwoven with and mixed up in the epistemic practices that are produced by messy links with both feminist activist resistance and institutionalized and professionalized academic feminisms.
\end{abstract}

Keywords: academic feminisms, disidentification, cruel optimism, everyday utopianism

\section{INTRODUCTION}

In this article ${ }^{1}$, I shall draw a personalized cartography of some epistemic habits regarding critique and affirmation in academic feminisms ${ }^{2}$. I shall focus on intertwined habits of disidentification, everyday utopianism, and cruel optimism. I consider these two first mentioned epistemic habits to have emerged out of academic feminisms' reliance on and emergence from feminist movements of protest. However, the third item in my cartography, cruel optimisms, will be discussed as interwoven with the institutionalization of academic feminisms within neoliberalized universities, and with the ensuing process of becoming disciplined in order to comply with neoliberal, capitalist governmentality and with different nation-state goals embodied by state universities.

Critical scrutiny of the academic habits of critical intellectuals, academic feminists included, seems to be urgent against the background of present-day academic conditions and political climates. Conditions for performing academic work, and for making a living as a critical intellectual, are becoming more and more subsumed by global trends of neoliberal commercialization and streamlining of academic education and knowledge production (Forstorp and Mellström 2013), even though national university systems have responded, and sometimes tried to resist the trend in uneven ways, depending on unequal geopolitical situations. These conditions will inevitably have

\footnotetext{
${ }^{1}$ I thank Dr. Elizabeth Sourbut for linguistic revision of the manuscript.

${ }^{2}$ I use the term academic feminism to refer to multiple types of theorizing, researching and teaching, which have managed to establish platforms in universities and academic institutions in many countries during the past four decades. I consider these kinds of academic theory and practice as having been established with a basis in links to political activism outside of the academy, but also as a result of activism within the academy. I understand the relationship with multiple kinds of feminist political activism (anti-racist, queer of colour, crip queer, trans, ecological, decolonial, postsocialist etc.) as a sine qua non for these academic endeavours.
} 
an impact on epistemic habits, and so will the need to counteract right wing agendas, which both in Europe and in the US are denying effects of climate change, and promoting xenophobic, racist, transphobic, anti-queer, antifeminist views, while at the same time excelling in homo-nationalism (Puar 2007), as well as in what can be defined as (gender)equality-nationalism (Martinsson, Griffin and Nygren 2016). But, as Bruno Latour, pointed out more than a decade ago (2004), well-established critical tools are not necessarily apt for navigating in these waters. According to Latour, some kinds of critique, for example, critical constructionism, which has been a hallmark of some kinds of leftist critiques, including some feminist ones, seem to 'run out of steam' (Latour 2004: 245), when confronted with massive amounts of 'fake news' and climate change denial. Other kinds of Western leftist and feminist critiques have found themselves caught up in epistemologies of ignorance (Sullivan and Tuana 2007), when confronted with decolonial, anti-racist and posthuman critiques (Spivak 2003; Chow 2006; Lionnet and Shih 2011; Tlostanova and Mignolo 2012; Haraway 2016), which pinpoint how, at the outset, humanities and social science disciplines, inter- and sub-disciplines, on which much critical intellectual work has been grounded, are blinded by tunnel visions as far as issues such as structural whiteness or beliefs in human exceptionalism are concerned.

Against this background, it seems timely, as suggested by the editors of this special issue, to review epistemic habits, which often are implicitly given rather than explicitly discussed. I shall try to contribute to this endeavour, taking a critical look at epistemic habits which have been important in my work as an academic feminist, located in the Northern region of Europe (Sweden and Denmark), and with longstanding and in-depth collaborative relations to feminist colleagues in other European countries (South, East and West), as well as to broader global constituencies of feminist scholars.

Firstly, I shall situate myself, accounting for my academic feminist practices which have formed my views and entry points to this reflection on epistemic habits. Secondly, I shall reflect upon the epistemic habits of disidentification (Butler 1993; Muñoz 1999) and everyday utopianism (Cooper 2014), embedded in the process of critical, but also affirmative, self-reflection to which I have been committed in my own academic and other activist feminist practices. Thirdly, I shall discuss the extent to which feminisms, unfolding within academic institutions, pervaded by the logics of global capitalism, including the neoliberalization and commercialization of knowledge production, as well as particular nation-state politics, are also bound to a performance of cruel optimism (Berlant 2011), which glosses over dilemmas and contradictions, reproducing epistemologies of ignorance. Fourthly, I shall reflect upon possibilities for changing one's epistemic habits, and advocate some changes.

\section{SITUATING MYSELF}

Assessed from a retrospective, genealogical perspective, the three habits of disidentification, everyday utopianism and cruel optimism, have been crucial to my trajectory as an academic feminist.

The epistemic habits of disidentification and everyday utopianism combine criticality with a quest for ways to affirmatively develop alternative futurities, figurations and worlding practices. This combination of critique and affirmation is what attracted me to feminism in the first place, around 45 years ago, in the shape of radical, anticapitalist feminism that emerged in tandem with the Western European and North American students' revolts of 1968. Although rather differently theorized today, this combination is still the reason why I see a plurality of feminisms, academic feminisms included, as embodying important societal forces, committed in multiple ways to a critical fostering of promising new figurations and worlding practices.

However, seen in retrospective, I must admit that the epistemic habit of cruel optimism has also been part of my trajectory from the early 1980s, when I hesitantly decided to take my commitment to socialist-feminist activism from the movement outside of academia to bear on transformatory work within academia, following the students' movement slogan from back then about the 'long march through the institutions' (Dutschke 1980).

So let me briefly describe this 'long march' to make the situated background of my reflections on epistemic habits more transparent.

I have for decades been involved in the building of feminist environments and institutions in academic settings in Scandinavia, but also in the broader European arena. Since the early 1980s, I have participated in the building of feminist research and educational programmes in Denmark and Sweden. For almost two decades in the 1990s and 2000s, I was also active in broad European curriculum development projects. Additionally, I have directed international research training schools in interdisciplinary gender studies, including a Nordic school with 40 partner universities from the five Nordic countries as well as from Russia, the Baltic States, Poland and The Netherlands.

Against a background of continuous collective, cross-border and cross-institutional reflections on these longstanding practices regarding the building of feminist institutions at different kinds of European universities, those of us who were engaged jointly in these activities became more and more aware of the possibility of contradictory and messy alliances which were necessary in order to make faculty boards and other university authorities authorize the funding of feminist research and study programmes and units. To a certain extent, it also 
became clear that such alliances, in particular, could be made within the framework of neoliberalized universities. Through these year-long discussions and practices, I learned about twisting neoliberal university agendas and making a feminist difference, performing what I came to name 'feminist hit-and-run-interventions' in academic institutions. In particular, I learned a lot, while comparing notes on university structures throughout Europe. Through this work, I came to understand how feminist colleagues, engaged in struggles to set up feminist teaching and research programmes in universities, which still had not become fully neoliberalized (i.e. universities which were still trying to hold on to 'old' academic degree systems), had sometimes harder struggles to fight than those who worked in more neoliberal environments.

Feminist teaching and research programmes were established faster and more smoothly in countries such as the UK and Sweden - countries in which universities became subsumed under neoliberal trends earlier than was the case in many other European countries. By contrast, such programmes had more difficulties in gaining footholds in countries such as Italy, Germany, and Denmark that kept up 'Bildungs'-traditions [learnednesstraditions] for longer, guarded by professors who considered themselves above such 'low and base' things as neoliberal knowledge commercialization and packaging of education in 'small' modulized building blocks such as separate bachelor's, master's and $\mathrm{PhD}$ degree programmes.

I know both the old and the new system from 'inside'. On the one hand, my academic degrees are products of the old European degree system, which, in my native country, Denmark, was still in place when I was a student and young scholar. These are degrees whose format and content are impossible to translate into the neoliberalized system. On the other hand, I have directed feminist research and study programmes in early neoliberalized Sweden for many years. Therefore, I immediately understood why it was so difficult for academic feminist colleagues in European countries with not yet fully neoliberalized university systems to establish platforms for feminist research and education. By contrast to the old system's massively long degrees, the neoliberalized university's small modules, handily packaged to be sold and to attract a diverse body of students in competition with other universities worldwide, could more easily be transformed into 'Gender Studies modules'. The Gender Studies modules were just one among many other small components in the neoliberalized university, and the administrators in charge of the new kinds of modulized educations cared more about numbers and formalized rules for accreditation than about ideologies about specific norms of learnedness. In this way, messy alliances and loopholes for feminist teaching programmes which also sustained feminist research endeavours could be created.

\section{CRITICALLY DISIDENTIFICATORY WORLDING PRACTICES}

I shall start my cartographic exploration of the interwoven epistemic habits of academic feminisms in which I have been immersed with the notion of disidentification (Butler 1993). Although it is located within different theoretical and political frameworks, giving different meanings to the concept, 'disidentification' is conceptualized as a subject position located in-between identification and counter-identification (the latter understood as active non-identification). I have discussed this in more detail elsewhere (Lykke 2014). Therefore, I shall not dwell on different definitions, but turn to Judith Butler's take on political disidentification (1993). Butler discusses how imagined political communities gathering under the banner of a unifying category (e.g. 'woman' or 'queer') must always fail to establish the unity which the signifier seems to promise. The performative political signifier can never capture the complex web of intersectional social relations in which the community's participants are always already embedded. According to Butler, participants will always be socioculturally more diverse than the singular category under which they organize. Some dimensions of the participants' diversity will always be excluded by the unifying signifier.

The consequences of the necessary failure of the unifying signifier are profound. The movement's participants commit themselves because they are drawn in by the unity which the signifier promises. But when the signifier inevitably fails to keep its promise, it leaves the participants with an 'uneasy sense of standing under a sign to which one does and does not belong' (Butler 1993: 219). According to Butler, the unease generated by the situation, produces disidentification, i.e. ambivalent feelings of simultaneously belonging and not-belonging. Even though this can lead to frustration and immobilization, Butler also hopefully asks about 'the possibilities of politicizing disidentification', suggesting that 'the failure of identification' can become 'the point of departure for a more democratizing affirmation of internal difference' (Butler 1993: 219).

I claim that Butler's analysis of political disidentification is important not only in relation to an understanding of social movements, but also for a discussion of epistemic habits of academic feminisms. This claim is motivated by the ways in which academic feminisms are related to feminist movements and often considered to be identity studies' (Wiegman 2012). On this basis, I find it reasonable to understand academic feminisms as embedded in patterns of disidentification. I have discussed elsewhere (Lykke 2014) how moments in the history of academic feminisms when disidentifications have become outspoken, have worked productively to prompt ground-breaking 
new scholarly-political work. But I also claim more generally that disidentification makes up an important epistemic habit of academic feminisms, having critical as well as affirmative potential.

To illustrate how disidentification can work in an academic context, I shall provide an ultrashort overview of my own scholarly work, read through the lens of disidentification.

When I look back at my academic and activist trajectory from the 1970s until now, with disidentification as a genealogical lens, the concept fits well. In hindsight, I seem almost always to have been prompted to theorize and write feminist theory in a passionate mood of disidentification. I have often started out with an embodied feeling of unease about the theoretical discourses that were popular in the academic and political communities to which I belonged. This was despite the fact that, like many other students and researchers, I felt attracted to them due to the explanatory power they seemed to hold in terms of giving plausible and critical theoretical accounts of power differentials, which appeared to be important. Nevertheless, I felt that these attractive theoretical frameworks lacked an understanding of other intersecting power differentials that to me were also important.

I started publishing in the mid-1970s - during the heyday of feminist and psychoanalytical Marxism. Along with other socialist feminists from the recently launched 'new' women's movement, I began my academic career back then as a critical socialist feminist intellectual, disidentifying with the Marxist focus on class relations that failed to take intersections of gender and class thoroughly into account. This disidentification led me to contribute to feminist Marxist theorizing of power differentials based on intersections of gender and class (Lykke 1993).

I also disidentified with the 'heteropatriarchal' analysis of subjectivities that I frequently saw being uncritically reproduced even in feminist research. Taking my point of departure in this disidentification, I conducted a queerlesbian-feminist-Marxist de- and reconstructive reading of the Freudian theory of femininity (Lykke 1993). I spent most of the 1980s on this part of my disidentification, carving out genealogies of lesbian desire, along with queer masculinities and femininities.

During the 1990s, I brought my disidentificatory approach to bear on the anthropocentric focus on human affairs in much feminist theory and politics. In this respect, I have contributed to the inclusion of cyborgs, 'earth others' (Plumwood 1993) and other non-human agencies in the discussion of the intersecting power differentials that need to be taken into account in feminist theorizing and politics (Bryld and Lykke 2000). This part of my disidentificatory research was carried out in collaboration with my lifepartner, Mette Bryld (who sadly passed away in 2014), who was a feminist scholar of Russian studies. Our joint research also included a disidentification with the methodological nationalism that characterized Nordic feminist research at the time. Our focus was a critical scrutiny of the re-enactment of colonialist discourses vis-à-vis the classic trinity, woman-native-nature in Russian and US post-WWII discourses.

Along with other post- and transdisciplinary feminists, I have also disidentified with endeavours to anchor feminist research exclusively within the frameworks of specific disciplines. Both theoretically and politically, I have tried to resist the policing power of disciplines, carving out spaces for the development of feminist research and teaching as the oxymoron of a postdisciplinary discipline (Lykke 2010). These and the other disidentifications which have characterized my life as a critical feminist intellectual have been extremely productive for my research processes.

To wrap up this personal example: I consider theoretical disidentifications in academic feminisms to be productive in terms of generating new theoretical frameworks. Moreover I see them as resonating with political disidentifications taking place in the contexts of social movements.

Against this background, I shall provide a slightly more elaborate framing of my take on disidentification as an epistemic habit of academic feminisms, closely related to activist practices directed towards change. To do so, I shall add that, alongside Butler's definition of political disidentification, an important inspiration for my reflections is the discussion of the concept framed by queer of colour scholar José Esteban Muñoz (1999). Muñoz presents the concept of disidentification in relation to queer of colour performance art. I find Muñoz' theoretical framing of disidentification, indebted not only to Butler, but also to Chicana feminists (Alarcón 1991; Sandoval 2000), useful for theorizing an important combination of criticality and new affirmative worlding practices. I see these as crucial for understanding the epistemic habit of disidentification, which I consider to be a key component of much feminism, academic feminisms included.

I also find it important that Muñoz' conceptualization of disidentification and his emphasis on the ways in which the notion combines criticality and affirmativity resonates with, but also cuts through, the divide between a hermeneutics of suspicion/paranoid readings and reparative readings. As suggested by Eve Kosofsky Sedgwick (2003), this has become a popular tool in some academic feminist circles for moving beyond merely negative modes of critique. There are resonances between Muñoz' and Sedgwick's frameworks in terms of their transgressions of such negative modes. However, Sedgwick's framing is somewhat haunted by the logics it seeks to overcome. Sustained by the work of psychoanalyst Melanie Klein (1988), Sedgwick struggles to establish the two kinds of reading (paranoid/critical and reparative/affirmative) not as mutually exclusive, but as oscillating from one to the other. However, because paranoid readings are established as a kind of straw man to be critically attacked in 
Sedgwick's text, while the concept of reparative readings is more summarily described, the text becomes caught up in the logics of negative critique that it set out to overcome. Sedgwick's analysis falls into a paradox, making a paranoid critique of paranoid readings. In contrast, Muñoz provides a carefully theorized conceptualization of disidentificatory performance art. He presents it as a combination of critical hermeneutics from the perspective of disempowered minority subjects and aesthetic performative worlding practices, which creates new worlds and opens up spaces for the unfolding of queer of colour subjectivities (Muñoz 1999: 25). He thus demonstrates that such art simultaneously practises critical and affirmative worlding.

A common feature which characterizes political disidentification in the context of social movements, but which I think also spills over into theoretical disidentifications in academic feminisms, is intensely vibrating affectivities. Disidentification - both political and theoretical - is about passions and desires. Strong affects are at stake and translated into powerful feelings. For example, the rage and frustration that emerge when you, as an embodied and intersectionally situated subject, experience that you and/or the group with which you identify are denied a speaking position within the overarching movement or theoretical enterprise under whose banner you signed up in order to get your critique heard; or when theoretical frameworks do not capture the complex intersections that you experience as crucial. To be relegated to the position of a mute object because parts of your intersectionally situated identity are denied space to emerge, politically and/or theoretically, is painful, in the context of both political movements and academic feminist communities, and causes rage and frustration. But these feelings can also transform into catharsis and joy when they are translated into theoretical work, conceptualizing both the muting mechanisms and their transgression.

To speak politically and conduct research in the name of disidentification is to carve out positions of enunciation, where foreclosed and/or denied aspects of your situated and embodied identity and the identity of the group with which you identify can unfold politically and be worked through theoretically. Let me use Kimberlé Crenshaw's seminal text on intersectionality (1991) as illustration. Crenshaw frames the disidentificatory point of departure for speaking about violence against women of colour as an urge to theorize positions that 'resist telling' (Crenshaw 1991: 1242), on the one hand, due to white middle-class feminists' way of ignoring black feminist perspectives, and, on the other hand, to black anti-racist movements' silencing of the particular issue of violence against women. Crenshaw's invention and theorizing of intersectionality is to be understood as her conceptual answer to the political problem represented by these stories that resist telling. In this sense, her position of enunciation is critically disidentificatory as well as affirmatively oriented towards creating foundations for other and better worlding practices, which take into account the previously silenced perspectives of women of colour.

It is also important to note that the critical political and theoretical disidentificatory practices that I discuss, should not be collapsed into general notions of critique. Since Kant, critique has, in various ways, been presented as the epitome of rational Enlightenment thought and its celebration of the free individual's rebellion against authoritarian modes of thinking in terms of, for example, state rules or religion. From the Frankfurt School to Foucault (1997) and Butler (2003), critique has also taken on a special meaning, relating to the figure of the critical leftist intellectual. When I transpose disidentification from activism to academia, suggesting it as a key habit of academic feminisms, it could easily be collapsed into critique in the more general sense of core academic value. Or it could be misunderstood as just another version of 'critique' in the above mentioned traditions, especially, as Danish philosopher Sverre Raffnsøe (2017) suggests, it seems possible to read a dimension of affirmation into notions of critique, as theorized from Kant to Foucault and Butler.

To avoid such misunderstandings, I shall end this section of the article, summarizing the ways in which the notion of disidentification, discussed here, brings issues to the fore, which, on the one hand, are not reflected in the philosophical debates on critique discussed above, but, which, on the other hand, holds a potential to enrich them. I shall suggest that the notion of disidentification, as theorized by Butler (1993) and Muñoz (1999), can productively address the question which bothered Foucault (1997) as well as Butler (2003) in their reflections on the notion of critique, namely: how to keep up a positive concept of critique without recurring to Kantian free will? What I suggest here is that thinking about the notion of critique along the lines of disidentification, makes it possible to understand what prompts the kind of theoretical and political, social movement-related critique, that I have discussed with academic feminisms as a case in point, from a postconstructionist ${ }^{3}$, and non-voluntaristic feminist perspective. The notion of disidentification thus opens towards an understanding of the ways in which this kind of critique can emerge from an embodied politics of location, affectively grounded in a collective resistance against intersecting power differentials, as well as from the ways in which the collective resistance always already fails to take into account all dimensions of the intersectionally embodied locations of its different members.

\footnotetext{
${ }^{3}$ As I have discussed it more elaborately elsewhere (Lykke 2010), I define postconstructionism as a theoretical stance which takes into account the ways in which constructionism considers subjects to be produced in discourse, while also, from a new materialist perspective, reflecting on the agencies of bodies and other materialities. Or as Karen Barad (2007) articulates this under the banner of agential realism, a stance which both reflects 'how discourse comes to matter' and 'how matter comes to matter'.
} 


\section{OPEN-ENDED EVERYDAY UTOPIANISM}

Epistemologies of hope and utopian thought in academic feminisms make up the next focus of my cartography. In different ways, the proximity to political movements and activism has, I suggest, also led much academic feminism to tap into utopianism. This is a utopianism that is defined open-endedly in the sense of the desire for a better world, but without fixed blueprints (Levitas 1990: 9). Feminist and other, related social movements gather in one way or another to make a change for the 'better' in society. They emerge out of the desire for a way of being that is different and 'better', broadly understood as less discriminatory, more socially and environmentally just than current ones. Utopian thought has been criticized for its modern focus on linear time, and for universalizing hegemonic, homogenizing and, thus, exclusionary blueprints for the 'good' life and society. However, other strands of utopian thought have distanced themselves from such frameworks, and instead focused on utopianism as a multiple and open anticipation of alternative futurities, which materialize momentarily as part of a messy 'here and now'. It is this latter form of utopian thought which I see as resonating, in particular, with broad strands of feminism, including much academic feminism, and which in this sense can be understood as belonging to the epistemic habits nurtured in academic feminist communities.

To elaborate on this claim, I shall draw on newer utopia studies, focusing on 'everyday utopias' (Cooper 2014). In common with the strands in utopia studies oriented towards open-ended and multiple futurities, feminist utopia studies scholar Davina Cooper defines 'everyday utopias' as utopian processes and moments which are always already mixed up with the societal mechanisms and forces of the here and now, for example, neoliberalism, which push or pull in different directions than utopian ones in the above-mentioned sense.

In order to distinguish utopian moments and processes in the midst of the chaotic messiness of everyday events, Cooper (2014) suggests that we look at the interplay between concepts, imaginations and actualizations. In her analysis of everyday utopias, she is particularly interested in tracing discrepancies and instances where the three are not aligned - in other words, where there are cracks and gaps between them. In the moments of smooth and seamless alignment, the dimensions of utopian endeavours and societal mechanisms pulling and pushing in different directions may not be easily distinguished. However, reflections on moments of discrepancies between concepts and imaginings, on the one hand, and actualizations on the other, may, according to Cooper, create more insight, and also be useful for an understanding of the cases where moments of smooth alignment may create blind spots.

Reviewing the epistemic habits of academic feminisms with Cooper's reflections on everyday utopianism in mind, the first thing that appears to me is the conceptual and imaginative levels that often distinguish themselves through their hope and belief in the possibility of change for the better, in terms of less discriminatory, more socially and environmentally just worlding practices. I argue that such an open and multiple conceptual and imaginative utopianism cuts across not only political feminisms, but also much feminist scholarship. Let me give some examples.

When Butler argues for 'the possibilities of politicizing disidentification' (Butler 1993: 219), and suggests that 'the failure of identification' may become 'the point of departure for a more democratizing affirmation of internal difference' (Butler 1993: 219), she is expressing a hope and the belief in a change for something 'better'. Indeed, in Eve Kosofsky Sedgwick's above-mentioned reflections on paranoid and reparative readings (2003), she uses Butler (1990) as an example of the paranoid ones. Butler can be read from other angles, though. It is noteworthy that Sedgwick criticizes Butler for an overly strong and even naive reliance on the transformative effects of exposing oppression. But this kind of exposure which Sedgwick immediately dismisses as unproductive paranoia, a simple revealing of what is already known, can instead be understood as a strong affirmative belief in, and hope and desire for, radically changed worlding practices.

To line up a few more examples, let me once more refer to Crenshaw, who taps into hope for a transformation for the better when she suggests intersectionality as a tool to tell the story of violence against women of colour which 'resists telling' (Crenshaw 1991: 1242). Along similar lines, Sandoval's (2000) notion of 'differential consciousness' and Alarcón's 'identities-in-difference' (1991) are also important and hopeful tools. When Braidotti argues for feminist figurations, as 'politically informed account $[\mathrm{s}]$ of (...) alternative subjectivity' (Braidotti 1994: 1) that include a vision towards which the subject is moving in an intellectual, emotional and bodily sense, she, too, is articulating a tool for open and multiple utopian thinking in feminism. Or we can draw upon Haraway's framing of the notion of 'worlding' as 'a permanent refusal of innocence and self-satisfaction with one's reasons and the invitation to speculate, imagine, feel, build something better' (Haraway 2008: 92). Worlding is here framed as yet another tool for open-ended utopian thought.

In these feminist texts, disidentifications, intersectional storytelling, differential consciousness, identities-indifference, figurations and worlding practices are all suggested as tools that can anticipate and facilitate work towards futurities which in a multiple and open-ended feminist sense are 'better' than the here and now. This list 
of examples is just a few among many, presented here to support my point about the significant open-ended utopian desire for change embedded in different strands of feminist thought and imagination.

The question about actualization in institutional practices is a different one. While conceptualizations and imaginations are embedded in hope for a better world, actualizations are taking place within arenas where tensions, messiness and contradictions emerge. I shall discuss these in the next section under the heading 'cruel optimism' (Berlant 2011).

\section{CRUEL OPTIMISM}

The epistemic habit of cruel optimism is also in its own way oriented towards happy futures, but in terms of individualist neoliberal ideologies. I think it would be naive to believe that it is possible to build feminist institutions within the neoliberal academy without being influenced by the context within which we are working. Or, in other words, I do not consider it possible to individually 'opt out' of the structural conditions and mechanisms of governmentality imposed by neoliberal, capitalist society. Therefore, I do not believe that any university-employed critical intellectual subject, academic feminists included, can avoid being shaped by current neoliberal discourses, modes of embodiment and transcorporeal organization. However, I do claim that the utopianism of academic feminisms (or other critical studies) cannot be totally reduced to cruel neoliberal optimism. I do not think that neoliberal governmentality works on subjectivities in a smooth, uncontradictory and unidirectional fashion; there are residues, excesses, cracks and loopholes, and productive powerplays in a Foucauldian sense may be initiated in these messy spaces.

While I consider that my epistemic habit of disidentification and my orientation towards an open-ended utopianism have emerged out of the relationship between academic feminisms and feminist movements, the last item in my cartography, cruel optimism, has a different genealogy. It is an epistemic habit which I see as embedded in the relationship between feminist academics, the institutionalization of academic feminisms in neoliberalized universities, and the ensuing process of becoming disciplined to comply with academic regimes of neoliberal governmentality. To help me sort out this epistemic habit, I draw upon the work of Lauren Berlant (2011), who defines 'cruel optimism' as an attachment of the neoliberal subject to a desired object which, in the end, will give the subject a very hard time, or it might even destroy the subject. But, formed within neoliberal governmentality, the subject can nevertheless not stop desiring and pursuing the desired object.

Berlant defines 'cruel optimism' as a relation that exists 'when something you desire is actually an obstacle to your flourishing' (Berlant 2011: 1). Furthermore, she emphasizes that 'these kinds of optimistic relation are not inherently cruel. They become cruel only when the object that draws your attachment actively impedes the aim that brought you to it initially' (Berlant 2011: 1). In line with this definition, I suggest that 'cruel optimism' can be considered an epistemic habit of academic feminisms. This provocatively raises the question of whether the project of institutionalizing academic feminisms in the neoliberal university is so much of a contradiction in terms that those engaging in it might be said to be pursuing an impossible goal - the pursuit of which prevents its own flourishing.

This question is not new. Throughout the history of the institutionalization of academic feminisms, we who promoted this have often been confronted with the question. Worriedly, we have asked ourselves and been challenged by critiques as to whether or not institutionalization would compromise our feminist goals so much that they would be destroyed by the process. Let me quote as an example a new self-reflexive and critical investigation of the geopolitical grammar of Nordic gender research 1975-2005 and its problematic use of the concept of the 'Nordic':

On an overarching level, we could argue that a central dilemma for women's and gender studies is one that concerns whether institutionalisation itself is a good idea for a field that was founded on the very critique of academic institutions. (Dahl et al. 2016: 71)

Looking into the rhetoric of institutionalization discourses as they have unfolded over several decades, we can see that they are, in many ways, immersed in a happy optimism, as thoroughly demonstrated by this investigation of academic feminist constructions of 'the Nordic'. I suggest, in Berlant's sense and with genealogical hindsight, that the particular kind of optimistic rhetoric which over the years has been mobilized to celebrate the process of institutionalization of academic feminism in the Nordic countries, can be considered cruel. On the one hand, it is a rhetoric that is strongly attached to the process of institutionalizing as a way to obtain an economically and institutionally sustainable platform for developing new feminist onto-epistemologies and new ethico-political forms of academic bonding, both crucial for feminist research. But, on the other hand, this rhetoric glosses over the destructive work of the neoliberal university. This runs from the ways in which the economic necessity to constantly submit funding applications radically mould not only the rhetoric of academic feminisms, but also the 
very goals we set up for our research, to the ways in which fierce competition for scarce jobs and resources is the everyday situation, from which no one in academia is exempt, feminists and non-feminists alike. The main line of argument of Dahl, Liljeström and Manns' book (2016) makes this very clear, taking institutionalization in the northern regions of Europe as its case study. The authors argue forcefully that constructions of an unproblematized - hegemonic, homogenizing, exclusionary and implicitly white - Nordicness is important to note and criticize as a blind spot of mainstream feminist research in the region during the period in question, when women's/gender/feminist studies units mushroomed at universities all over the region.

The chapter covering the first part of the period of institutionalization during the 1970s and ' 80 s, for example, uses an analysis of the optimistic construction of self-satisfied Nordic difference to note how it created a hegemonic homogeneity, glossing over many dissenting views:

A general perception at the time seems to have been that dissentions concerning theoretical and political issues were likely to threaten a fragile unity that was needed in order to get a foothold in academia. Therefore, disagreement was put aside easily, even though there were large differences between standpoints on aims, objects, theories, and methods. (Dahl et al. 2016: 46)

Against the background of memory work on the same period, throughout which I was active as an academic feminist, I would like to add here that not only were theoretical and political discrepancies glossed over, but the spaces were definitely not as purely welcoming and different from the rest of academia as they are claimed to be in cruelly optimistic texts on institutionalization written back then (Dahl et al. 2016). They were instead permeated by personal fights over scarce resources and hard competition for far too few relevant jobs for feminist academics, especially those wanting to work with feminist theory and analysis. In this sense, these feminist spaces resembled the rest of academia, and were perhaps even more competitive, because jobs were fewer in academic feminism than in traditional disciplines. Moreover, the precarious situation of those fighting for the jobs was often proportionately greater due to the general mechanisms of discrimination against women, who made up the majority of participants flocking in and around academic feminist institutions. I know of feminist professors, well-known today, who back then were part-time teaching assistants in precarious situations and who were escaping to the toilets to hide their tears of rage and frustration about the 'welcoming space' (Dahl et al. 2016). I have also, in the midst of this 'welcoming space' heard different kinds of homophobic hate-speech such as claims about 'lesbian conspiracies' to help lesbian feminists into jobs while leaving heterosexual feminists in limbo. Thus, not only were theoretical discrepancies sometimes, albeit not always, kept behind the scenes, when the rhetorics of feminist unity, hope, optimism and sisterhood were constructed, so were the ways in which neoliberal working conditions took a heavy toll on feminist ethics of solidarity and collectivity.

Following Berlant, I interpret this situation through the lens of a cruelly optimistic attachment to an impossible goal. On the one hand, there was a passionate rhetoric of alternative feminist warmth and gestures towards happy research and teaching collectives and harmonious feminist institutions. On the other hand, it is clear that even these kinds of institutions must be understood as always already permeated by structurally imposed, neoliberal conditions that promoted individualism and strongly competitive conflict. However, in line with my cartography as a whole, I also claim that these academic feminist institutions gave rise not only to the unfolding of hegemonic and cruel optimisms, but also to critically disidentificatory conceptualizations, imaginations, worlding practices and open-ended everyday utopianisms, including ethics of caring and collectivity. I, thus, consider these institutions as best understood as unruly spaces where neoliberal cruel optimisms, critical disidentifications and feminist utopian worlding practices are messily performed as entangled in each other.

\section{CAN EPISTEMIC HABITS BE CHANGED?}

I am hopeful enough to believe that epistemic habits can be changed for the better, and I think that the collective disidentificatory practices and everyday utopian orientations which have contributed to the shaping of feminist politics and theorizings testify to this. However, it is hard work, and the result is definitely not pre-given. The ways in which disidentifications and everyday utopianism can become interwoven with cruel, neoliberally framed optimism demonstrate that failure is as likely an outcome as success when it comes to changing such habits for the better in an open-ended feminist utopian sense.

In the final section of this article, I shall discuss what I see as a couple of important prerequisites for catalyzing change in the current situation: attentiveness to the effects of changing conditions of academic knowledge production, and indepth reflections on its geopolitical grammars. The impact of both these dimensions on academic feminisms and epistemic habits have been undertheorized. Even though situated knowledges and the politics of location are often cited as key to feminist theorizing, these particular aspects of situatedness are often taken for granted, and have come to figure as blind spots. 
Even though I emphasize cruel optimism as part of my cartography of epistemic habits, I do not, as mentioned, wish to merely dismiss academic feminisms as purely embedded in neoliberal modes of thinking and acting. Instead, I am arguing for the importance of admitting to cruel optimism when trying to understand the epistemic habits of an academic feminism which, on the other hand, cannot be restlessly reduced to this kind of neoliberally induced epistemic habit. Therefore, studies are much needed that critically sort out those dimensions of epistemic habits which are effects of neoliberal working conditions. I have tried to develop my cartography along such lines. But to change epistemic habits in this regard will also include fully exploring the paradoxical intra-actions of feminist activism and neoliberalized university.

It is part of current neoliberal conditions that the grounds on which feminist academic institutions such as Centres and other units for Women's, Gender or Feminist Studies stand are paradoxical and pervaded by contradictions. To briefly elaborate upon these contradictions and tensions, which I suggest that academic feminists should take more thoroughly into account when critically scrutinizing epistemic habits, I shall refer to the discussion about the transformation from so-called mode 1 academic knowledge production to mode 2 (Gibbons et al. 1994; Nowotny et al. 2001). In creating a better understanding of the conditions for the epistemic habits of academic feminisms, I think it is illuminating to consider mode 2 knowledge production as fitting the bill of neoliberalism, while, in paradoxical ways, also sometimes generating platforms for transgressive disidentificatory criticalities and utopian worlding practices.

According to Gibbons et al. (1994) and Nowotny et al. (2001), mode 1 knowledge production is disciplinary and characterized by homogeneity and stable academic hierarchies, based on gender/sex, race, ethnicity and class. By contrast, mode 2 is transdisciplinary and characterized by heterogeneity, commercialization, dependence on external funding, more ad hoc structures and 'massification' (mass admission of students). While mode 1 universities, in their classic form, were elitist and exclusive, admitting primarily young white men from the upper and middle classes, transformations into mode 2 implies a massification of student populations. Even though these new student populations in particular have a background in the quickly growing middle classes, and social inequalities in terms of class and racialization are clearly profiled (Brade 2017), the massified student populations, nevertheless, changes the foundations of universities radically, posing new questions and making new demands.

When I discuss mode 1 and mode 2 in this way, a certain historicity is at stake, in the sense that mode 2 knowledge production is claimed currently to become more widespread in tandem with neoliberalism, and globalized and commercialized knowledge production. But, according to Gibbons et al. (1994), and Nowotny et al. (2001), the two modes should be understood as neither mutually exclusive nor as two separate points on a linear historical timeline. As mentioned in the introduction, while neoliberalization is taking place on a global scale, different national university politics as well as unequal global relations make materializations happen very unevenly.

In its classic form, the mode 1 university was an institution, governed by white, well-off men from the bourgeois classes, deeply convinced about their right to supremacy over their gendered, classed, racialized, colonialized, animalized, sexualized, disabled etc. others. There was not much doubt among the representatives of that university that white men (i.e. the version of the human who perfectly mirrored themselves) were exceptional, and had a right, given directly by the Christian God (no other gods counted), to rule, control, objectify and classify all human and non-human others. Confirming this exceptionalism, and narcissistically enjoying the convenient powers it gave to those in charge of the classic mode 1 university, was basically what many of its scientific endeavours were designed to do.

The foundations (albeit not its institutional echoes in the shape of disciplines, ontologies and epistemologies) of the classic mode 1 university are today becoming more and more eroded by transnational neoliberal capitalism sweeping across the world, transforming knowledge production into a commercialized business, producing consumer goods. Even critical knowledge is nowadays generated in the shape of consumer goods, when transformed into publications by commercial publishers or university courses to be sold on the market.

However, it is also worthwhile noticing that, according to Gibbons et al. (1994), and Nowotny et al. (2001), the foundations of the mode 1 university are being undermined not only by transnational neoliberal capitalism, but also by massification of student populations - i.e. by the opening up of universities worldwide to massive numbers of new students' groups with intersectionally different backgrounds, differing from the white male European and US upperclass elites which exclusively populated classic mode 1 universities. Even though these kinds of academic elites (like other powerful throwbacks to mode 1) still hold much positional power, their power is not as unchallenged as it used to be.

When considering the history of the students' movement in the aftermath of the 1968 revolt, its alliances with workers' and anti-imperialist movements, protesting the Vietnam war, the Israeli occupation of Palestine and apartheid in South Africa, and its attempts to theorize these fights under the banner of Marxism in universities, it seems pertinent to acknowledge that the challenges coming from massification actually helped to undermine the mode 1 university, epistemologically, politically and organisationally. Moreover, it is important to acknowledge that the massification of student populations since then have given rise to ever-renewed revolts which have happened 
and continue to happen in many places all over the world (for example Tiananmen Square 1989 in China, and present-day South Africa, \#FeesMustFall), and that a political effect of this worldwide massification has been and is a proliferation of critical studies of all kinds - decolonial, anti-racist, feminist, queer, transgender studies. Massification has happened in tandem with students' movements, which have prompted many kinds of radical criticality that in varying degrees and unevenly geographically distributed have succeeded in gaining space and making an impact on academia worldwide, creating spaces for everyday utopianism.

The neoliberalizisation of universities is, thus, fraught with tensions and productive contradictions which need to be strategically taken into account. But to do so demands new epistemic habits and self-reflexivity on new levels. I suggest that it requires the collective development and nurturing of epistemic cultures in which the thinking through of the societal and material context of one's knowledge production figures as one of the important criteria for good research.

I shall also suggest that these much-needed new reflections on context and conditions for one's knowledge production should include a taking into account of the geopolitical grammars in which one's research is embedded. When framing this requirement with reference to the concept of geopolitical grammars, I am indebted to the aforementioned volume by Dahl, Liljeström and Manns (2016), which develops this concept as a critique of the ways in which constructions of the 'Nordic' in academic feminisms in the northern regions of Europe has been represented as a taken-for-granted and unscrutinized blind spot.

It goes without saying that the onto-epistemological and methodological move suggested here by Dahl et al. (2016) has importance beyond the northern regions of Europe. But again, it is also important to notice that such a move is more easily discussed than performed. Many disciplines, sub-disciplines and interdisciplines are pervaded by epistemic habits of methodological nationalism/regionalism, universalization and the use of geopolitical distinctions that are too crude and homogenizing, and many academic research traditions have established these approaches as their horizon. Academic feminisms are part of this landscape, and are also, in many ways, affected by this predicament and the lack of tools to go beyond this state of affairs. To transgress the logics of problematic geopolitical grammars, therefore, requires a deepened critique of the disciplines, sub-disciplines and interdisciplines.

Here, too, I think it is urgent to nurture and encourage a rethinking of epistemic habits. But it is also important to recognize that transgressions of these limited and problematic outlooks are already on the agenda of some current strands of theorizing and analysing, including both converging and differing feminist ones, such as decolonial feminisms (Tlostanova and Mignolo 2012), postcolonial feminisms (Mohanty 1988) transnational feminisms (Kaplan, Alarcón, and Moallem 1999), postsocialist feminisms (Atanasoski and Vora 2017), and subaltern theories (Spivak 1988).

\section{CONCLUSION}

I have critically reviewed three epistemic habits: disidentifications, everyday utopianism and cruel optimism and drawn a personalized cartography of epistemic habits in current academic feminisms. I consider these habits to be interwoven, so even though the first two are, in my view, to be valued positively and need to be further elaborated, the interweaving with the problematic third one, cruel optimism, needs also to be thoroughly considered. Moreover, I have suggested expanding our epistemic habits to include critical scrutiny of the impact of neoliberal working conditions on academic feminist knowledge production and more in-depth reflections on geopolitical grammars. Both epistemic moves should be integrated more fully into the approaches of academic feminisms.

As I have emphasized throughout, my focus is on a cartography of epistemic habits that have meant a lot to me in my personal enactment of academic feminisms, located in the northern region of Europe. In saying this, I do not mean to suggest that I could have articulated them in this way at the time. But, in genealogical hindsight, reviewing my 45-year-long engagement with feminist activism, theorizing and the professionalization of academic feminisms in the shape of institution building, I see them as important to my approaches.

I have also expressed the hope that epistemic habits can be changed, and I have advocated changes that I believe to be important in the current global situation. I see reflections such as those that the editors of this special issue have encouraged the contributors to perform in terms of reviewing epistemic habits to be a productive step towards fostering such changes when it comes to overcoming habits built on epistemologies of ignorance and to the fostering of new and better habits. However, I do also think that it is important to be modestly aware that a situation of total transparency and complete transcendence of such epistemologies can never be achieved. This would require a god-trick which, with Haraway (1991), I reject as a positivist illusion. But I do believe that listening to the challenges brought by ever-new critically worlding and feminist disidentifying voices is of utmost importance. I would also argue that academic feminist institutions should act as gate-openers rather than gatekeepers, welcoming such disidentifications and establishing transversal dialogues (Yuval-Davis 1997) to work collaboratively with them. In this way, these institutions should try to create new synergies and alliances, and new 
open-ended everyday utopian worlding practices, still taking into account the messiness that often enters into the picture when moving from conceptualizations and imaginations to actualizations. As Cooper (2014) reminds us, everyday utopias are neither purely utopian, nor purely caught up in destructive logics of the here and now. They are messy, but in a hopeful way.

\section{REFERENCES}

Alarcón, N. (1991). The Theoretical Subject(s) of 'This Bridge Called My Back' and Anglo-American Feminism. In: H. Calderon and J.D. Saldivar, eds., Criticism in the Borderlands: Studies in Chicana Literature, Culture and Ideology (pp. 28-43). Durham and London: Duke University Press.

Atanasoski, N. and Vora, K. (2017). Postsocialist Politics and the End of Revolution. Social Identities, 23(4), pp. 116. https://doi.org/10.1080/13504630.2017.13211712

Barad, K. (2007). Meeting the Universe Halfway: Quantum Physics and the Entanglement of Matter and Meaning. Durham and London: Duke University Press.

Berlant, L. (2011). Cruel Optimism. Durham and London: Duke University Press.

Brade, L.H. (2017). Vi, de neutrale. Skitser til udfordring af akademisk forstehed. Lund: Lunds universitet, Samhällsvetenskapliga fakulteten. Genusvetenskapliga institutionen.

Braidotti, R. (1994). Nomadic Subjects: Embodiment and Sexual Difference in Contemporary Feminist Theory. New York: Columbia University Press.

Bryld, M. and Lykke, N. (2000). Cosmodolphins: Feminist Cultural Studies of Technology, Animals and the Sacred. London: Zed.

Butler, J. (1990). Gender Trouble: Feminism and the Subversion of Identity. London and New York: Routledge.

Butler, J. (1993). Bodies that Matter: On the Discursive Limits of "Sex". London and New York: Routledge.

Butler, J. (2003). What is Critique? An Essay on Foucault's Virtue (2000). In: S. Salih with J. Butler, eds., The Judith Butler Reader (pp. 302-322). Malden, MA: Blackwell.

Chow, R. (2006). The Age of the World as Target. Self-Referentiality in War, Theory, and Comparative Work. Durham and London: Duke University Press.

Cooper, D. (2014). Everyday Utopias. The Conceptual Life of Promising Spaces. Durham and London: Duke University Press.

Crenshaw, K. (1991). Mapping the Margins: Intersectionality, Identity Politics, and Violence against Women of Color. Stanford Law Review, 43(6), pp. 1241-1299.

Dahl, U., Liljeström, M. and Manns, U. (2016). The Geopolitics of Nordic and Russian Gender Research, 1975-2005. Stochkholm: Södertörn Academic Studies.

Dutschke, R. (1980). Mein langer Marsch: Reden, Schriften und Tagebücher aus zwanæig Jabren. Hamburg, DE: Rowohlt.

Forstorp, P. and Mellström, U. (2013). Eduscapes: Interpreting Transnational Flows of Higher Education. Globalisation, Societies and Education, 11(3), pp. 335-358.

Foucault, M. (1997). What is Critique?. In: S. Lotringer, ed., The Politics of Truth (pp. 41-83). Transl. L. Hochroth and C. Porter. New York: Semiotext(e).

Gibbons, M., Limoges, C., Nowotny, H., Schwartzman, S., Scott, P. and Trow, M. (1994). The New Production of Knowledge: The Dynamics of Science and Research in Contemporary Societies. London: Sage.

Haraway, D. (1991). Situated Knowledges: The Science Question in Feminism and the Privilege of Partial Perspective. In: Simians, Cyborgs and Women: The Reinvention of Nature (pp. 183-201). London: Free Association Books.

Haraway, D. (2008). When Species Meet. Minneapolis: University of Minnesota Press.

Haraway, D. (2016). Staying with the Trouble: Making Kin in the Chthulucene (Experimental Futures). Durham and London: Duke University Press.

Kaplan, C., Alarcón, N. and Moallem, M. (eds). (1999). Between Woman and Nation. Durham and London: Duke University Press.

Klein, M. (1988). Envy and Gratitude. London: Virago.

Latour, B. (2004). Why Has Critique Run Out of Steam? From Matters of Fact to Matters of Concern. Critical Inquiry, 30, pp. 225-248. The University of Chicago. https://doi.org/10.1086/421123

Levitas, R. (1990). The Concept of Utopia. Oxford: Peter Lang.

Lionnet, F. and Shih, S. (eds). (2011). The Creolization of Theory. Durham, London: Duke University Press.

Lykke, N. (1993). Rotkäppchen und Oedipus. Zu einer feministischen Psychoanalyse. Wien: Passagen Verlag.

Lykke, N. (2010). Feminist Studies: A Guide to Intersectional Theory, Methodology and Writing. New York: Routledge.

Lykke, N. (2014). Passionate Disidentifications as an Intersectional Writing Strategy. In: N. Lykke, ed., Writing Academic Texts Differently: Intersectional Feminist Methodologies and the Playful Art of Writing (pp. 30-47). New York: Routledge. 
Martinsson, L., Griffin, G. and Giritly Nygren, K. (eds). (2016). Challenging the Myth of Gender Equality in Sweden. Bristol: Policy Press.

Mohanty, C.T. (1988). Under Western Eyes: Feminist Scholarship and Colonial Discourses. Feminist Review, 30, pp. 49-74.

Muñoz, J. E. (1999). Disidentifications: Queers of Color and the Performance of Politics. Minneapolis and London: University of Minnesota Press.

Nowotny, H., Scott, P. and Gibbons, M. (2001). Re-Thinking Science: Knowledge and the Public in an Age of Uncertainty. Cambridge: Polity.

Plumwood, V. (1993). Feminism and the Mastery of Nature. London and New York: Routledge.

Puar, J. (2007). Terrorist Assemblages. Homonationalism in Queer Times. Durham and London: Duke University Press.

Raffnsøe, S. (2017). What is Critique? Critical Turns in the Age of Criticism. Outlines - Critical Practice Studies, 18(1), pp. 28-60. Available at: https://tidsskrift.dk/outlines/article/view/26261

Sandoval, C. (2000). The Methodology of the Oppressed. Minneapolis and London: University of Minnesota Press.

Sedgwick, E.K. (2003). Touching Feeling: Affect, Pedagogy, Performativity. Durham and London: Duke University Press.

Spivak, G.C. (1988). Can the Subaltern Speak?. In: C. Nelson and L. Grossberg, eds., Marxism and the Interpretation of Culture (pp. 271-313). Basingstoke: Macmillan Education.

Spivak, G.C. (2003). Death of a Discipline. New York: Columbia University Press.

Sullivan, S. and Tuana, N. (eds). (2007). Race and Epistemologies of Ignorance. Albany: State University of New York Press.

Tlostanova, M. and Mignolo, W. (2012). Learning to Unlearn. Decolonial Reflections from Eurasia and the Americas. Columbus, Ohio: Ohio State University Press.

Wiegman, R. (2012). Object Lessons. Durham and London: Duke University Press.

Yuval-Davis, N. (1997). Gender \& Nation. London: Sage.

Citation: Lykke, N. (2017). Academic Feminisms: Between Disidentification, Messy Everyday Utopianism, and Cruel Optimism. Feminist Encounters: A Journal of Critical Studies in Culture and Politics, 1(1), 03. https://doi.org/10.20897/femenc.201703

Copyright (C) 2017 by Author/s and Licensed by Lectito BV, Netherlands. This is an open access article distributed under the Creative Commons Attribution License which permits unrestricted use, distribution, and reproduction in any medium, provided the original work is properly cited. 